\title{
Reaction of coffee genotypes to different populations of Meloidogyne spp.: detection of a naturally virulent $M$. exigua population
}

\author{
Maria de Fátima S. Muniz ${ }^{1}$, Vicente P. Campos ${ }^{2}$, Antônio W. Moita ${ }^{3}$, Wallace Gonçalves ${ }^{4}$, Maria Ritta A. \\ Almeida ${ }^{5}$, Fábio Rodrigues de $\operatorname{Sousa}^{5}$ \& Regina Maria D. G. Carneiro \\ ${ }^{1}$ Centro de Ciências Agrárias, Universidade Federal de Alagoas, 57100-000, Rio Largo, AL, Brazil; ${ }^{2}$ Departamento de \\ Fitopatologia, Universidade Federal de Lavras, 37200-000, Lavras, MG, Brazil; ' ${ }^{3}$ Embrapa Hortaliças, 70359-970, Brasília, \\ DF, Brazil; ${ }^{4}$ Instituto Agronômico de Campinas - IAC, 13001-970 Campinas, SP, Brazil; ${ }^{5}$ Embrapa Recursos Genéticos e \\ Biotecnologia, 70849-979, Brasília, DF, Brazil
}

Author for correspondence: Maria de Fátima S. Muniz, e-mail: mf.muniz@uol.com.br

\begin{abstract}
The reaction of seven genotypes of Coffea arabica to 10 Meloidogyne spp. populations collected mainly from coffee plantations in Brazil and Costa Rica was evaluated under greenhouse conditions. The inoculum consisted of 10,000 eggs per plant. Evaluations were done 8 months after inoculations considering the root fresh weight, gall and egg mass indices, number of eggs per gram of root and reproduction factor (RF). The cultivars Obatã IAC 1669-20, Sarchimor IAC 4361 and Tupi Amarelo IAC 5111 exhibited susceptibility to the four Brazilian M. exigua populations tested. However, cv. Tupi Vermelho IAC 1669-33 revealed resistance (RF value of 0.7) to the M. exigua population from Lavras, Minas Gerais State, Brazil. A population of M. exigua from Bom Jesus de Itabapoana, Rio de Janeiro State, Brazil, was highly virulent on cv. IAPAR 59 ( $R F=165.7)$, bearing resistance gene Mex-1, and was also virulent on genotype Paraíso (H 419-5-4-5-2) $(\mathrm{RF}=396.2)$. A Meloidogyne sp. population on coffee from Garça, São Paulo State, Brazil, reproduced at low rates (RF ranging from 0.1 to 3.9) on all genotypes. All tested cultivars were susceptible to M. incognita and M. paranaensis. M. mayaguensis of guava from Paraná State, Brazil, reproduced at low rates in all coffee genotypes; however, another population of coffee, from Costa Rica, was more aggressive and showed RF value that ranged from 0.8 to 12.4. Results of this study point for the first time to the ability of a naturally occurring $M$. exigua population to overcome the resistance conferred by the Mex-1 gene.
\end{abstract}

Keywords: Coffea arabica, resistance, susceptibility, root-knot nematodes

\section{RESUMO}

Reação de genótipos de cafeeiro a diferentes populações de Meloidogyne spp.: deteç̧ão de uma população de M. exigua naturalmente virulenta

A reação de sete genótipos de Coffea arabica a 10 populações de Meloidogyne spp. coletadas principalmente em plantios de café no Brasil e Costa Rica foi avaliada em casa de vegetação. O inóculo consistiu de 10.000 ovos por planta. As avaliações foram realizadas 8 meses após as inoculações considerando-se a massa da matéria fresca das raízes, índices de galhas e massas de ovos, número de ovos por grama de raiz e fator de reprodução (FR). As cultivares Obatã IAC 1669-20, Sarchimor IAC 4361 e Tupi Amarelo IAC 5111 exibiram suscetibilidade às quatro populações brasileiras de M. exigua. Entretanto, cv. Tupi Vermelho IAC 1669-33 mostrou-se resistente $(\mathrm{FR}=0,7)$ a uma população de M. exigua proveniente de Lavras, MG, Brasil. A população de M. exigua oriunda de Bom Jesus de Itabapoana, RJ, Brasil foi altamente virulenta à cv. IAPAR 59 ( $\mathrm{FR}=165,7)$, portadora do gene de resistência Mex-1 e ao genótipo Paraíso (H 419-5-4-5-2) (FR=396,2). A população de Meloidogyne sp. do cafeeiro, Garça, SP, Brasil, reproduziu-se em baixos níveis $(\mathrm{FR}=0,1-3,9)$ sobre todos os genótipos. Todas as cultivares testadas foram suscetíveis a $M$. incognita e $M$. paranaensis. A reprodução de $M$. mayaguensis obtida de goiabeira, PR, Brasil, foi baixa (FR = 0,0-1,6), em todos os genótipos. Entretanto, outra população obtida do cafeeiro na Costa Rica apresentou valores de FR que variaram de 0,8 a 12,4. Os resultados deste trabalho mostraram, pela primeira vez, a capacidade de uma população de $M$. exigua obtida em campo de superar a resistência conferida pelo gene Mex-1.

Palavras-chave: Coffea arabica, resistência, suscetibilidade, nematóides de galha.

\section{INTRODUCTION}

Root-knot nematodes of the genus Meloidogyne are more widely distributed throughout the world in coffee

Part of the Doctoral Thesis of the first author. Universidade Federal de Lavras. Lavras MG. 2007.
(Coffea arabica L.) plantations than any other major group of plant-pathogenic nematodes. In Brazil, the most common, damaging and well-known species are M. exigua Göldi, 1887, M. incognita (Kofoid \& White, 1919) Chitwood, 1949 and M. paranaensis Carneiro, Carneiro, Abrantes, Santos \& Almeida, 1996 (Campos \& Villain, 2005). Among the most damaging species, M. exigua is especially common 
in Latin America, where it constitutes a major agronomic constraint. This species is widespread in coffee-producing states in Brazil. Meloidogyne incognita occurs in many coffee-growing areas around the world, but it is in Brazil that its effects on coffee plantations have become most serious (Campos \& Villain, 2005). In 1996, a new species of the genus Meloidogyne was described in the State of Paraná, Brazil and designated as M. paranaensis (Carneiro et al., 1996). According to Campos \& Villain (2005), $M$. paranaensis is as destructive to coffee plantations as $M$. incognita, especially in the states of Paraná and São Paulo (Carneiro et al., 2005). This species was also detected in Guatemala and Hawaii (Carneiro et al., 2004).

Meloidogyne mayaguensis Rammah \& Hirschmann, 1988 seems to be a polyphagous species widespread in many African and American countries (Carneiro, 2003). In Cuba, it is the most damaging species on coffee (Rodríguez et al., 1995). In Brazil, this species is an economically important plant pathogen on guava (Psidium guajava) but not detected in coffee under field conditions (Carneiro et al., 2001, 2006). In addition, it has been found infecting many other crops (Almeida et al., 2008). The host response of coffee cultivars to this species is unknown.

The application of nematicides, crop rotations in areas where old coffee plants have been eradicated, planting in pathogen-free soil, the use of healthy seedlings, resistant rootstocks and resistant cultivars are methods used for controlling coffee root-knot diseases (Campos \& Villain, 2005). According to Roberts (2002), plant resistance has been found and developed mainly for the highly specialized parasitic nematodes that have a sedentary endoparasitic relationship with their host. Resistance is used to describe the ability of a plant to suppress development or reproduction of the nematode. It can range from low to high resistance. A completely or highly resistant (HR) plant allows no nematode reproduction, or only trace amounts. Partially or moderately (MR) resistant plants allow some intermediate amounts of reproduction. Susceptibility $(\mathrm{S})$ is used as the opposite of resistance; thus a susceptible plant allows normal nematode development and the expression of any associated disease. However, resistance may lack durability due to variability in the nematode population (Starr et al., 2002).

Several lines derived from the interspecific cross between $C$. arabica and $C$. canephora Pierre ex Froehner (Timor Hybrid) showed resistance to M. exigua similar to that observed on C. canephora (Silvarolla et al., 1998; Bertrand et al., 2001). Recently, a major gene designated Mex-1 locus introgressed from C. canephora was identified. This gene possibly presented an incomplete dominant expression (Noir et al., 2003). There are no studies showing the spectrum of resistance of the gene Mex-1 to different populations of $M$. exigua. Resistance or tolerance to $M$. incognita has been found only in coffee genotypes derived from C. canephora (Carneiro, 1995; Gonçalves et al., 1996). For M. paranaensis, resistance has been found in both $C$. canephora germplasm and Ethiopian $C$. arabica accessions (Anzueto et al., 2001; Campos \& Villain, 2005).

Considering the great diversity in Meloidogyne spp. populations on coffee (Randig et al., 2002; Carneiro et al., 2004; Hernandez et al., 2004; Muniz et al., 2008), and the fact that resistance may lack durability due to variability in the nematode population (Starr et al., 2002) it is of prime importance to assess the pathogenicity of Meloidogyne species and biotypes (races or enzymatic phenotypes) to different coffee cultivars, so as to implement integrated management strategies. The present study investigated the pathogenicity and virulence of ten different Meloidogyne spp. populations on seven coffee genotypes.

\section{MATERIALS AND METHODS}

\section{Nematode populations, multiplication and inoculation}

Ten nematode populations originated from infected coffee and guava roots were used (Table 1). The populations were characterized by perineal pattern, races, esterase phenotypes and/or SCAR (sequence-characterized amplified region) markers using the techniques proposed by Hartman \& Sasser (1985), Carneiro \& Almeida (2001) and Randig et al. (2002).

The populations were multiplied on coffee $\mathrm{cv}$. Catuaí Vermelho IAC 144 (Mexi 1, Mexi 3, Mexi 4, Minc 6 and Mpar 8) or tomato (Lycopersicon esculentum group Santa Cruz cv. Kada, populations Mexi 2, Minc 5, Msp 7, Mma 9 and Mma 10) roots under greenhouse conditions. To recover the inoculum, 3-month-old tomato roots or 6-month-old coffee roots were cut into 1-2 cm segments and blended for 1 minute in a $0.5 \%$ sodium hypochlorite solution (Barker, 1985). Eggs were rinsed thoroughly and counted in $1 \mathrm{ml}$ aliquots in Peter's counting slide. Means of three replicates were used to represent the number of eggs per $\mathrm{mL}$. Single 6-month-old coffee plants grown in 3-liter plastic pots containing 1:1:1 mixture (v/v) autoclaved soil, bovine manure and sand were inoculated with approximately 10,000 eggs of each nematode. The inoculum was applied onto the soil surface around the stem base. Plants were arranged in a randomized complete block factorial design (10 Meloidogyne spp. populations x 7 coffee genotypes) with eight replicates. Plants were grown with regular watering and fertilization.

\section{Experiment and plant material}

The trial was carried out in a greenhouse at temperatures ranging from 22 to $28^{\circ} \mathrm{C}$. All cultivars tested are currently used by farmers in Brazil. Varieties studied are originated from the parental group 'Sarchimor', formed by the cultivars Obatã IAC 1669-20, Tupi Vermelho IAC 1669-33, Tupi Amarelo IAC 5111, Sarchimor IAC 4361 and IAPAR 59, all of them derived from a cross between the cv. 'Villa Sarchi' and the 'Timor Hybrid CIFC 832/2'. The cultivar Paraíso (H 419-5-4-5-2) derived from 'Catuaí Amarelo IAC 30 x Timor Hybrid UFV 445-46 (CIFC 2570)’ 
M.F.S. Muniz et al.

Table 1 - Meloidogyne spp. populations used for coffee genotype evaluations

\begin{tabular}{|c|c|c|c|}
\hline $\begin{array}{l}\text { Population } \\
\text { code }\end{array}$ & Geographical origin & Species/Race & $\begin{array}{c}\text { Esterase } \\
\text { phenotype }\end{array}$ \\
\hline Mexi 1 & Lavras - MG, Brazil & M. exigua race 1 & E1 \\
\hline Mexi 2 & Lavras - MG, Brazil & M. exigua race 2 & E2 \\
\hline Mexi 3 & Bom Jesus de Itabapoana - RJ, Brazil & M. exigua race 1 & E1 \\
\hline Mexi 4 & Campinas - SP, Brazil & M. exigua race 1 & E2 \\
\hline Minc 5 & Avilândia - SP, Brazil & M. incognita race 1 & I1 \\
\hline Minc 6 & Londrina - PR, Brazil & M. incognita race 3 & $\mathrm{I} 2$ \\
\hline Msp 7 & Garça - SP, Brazil & Meloidogyne sp. & S2 \\
\hline Mpar 8 & Londrina - PR, Brazil & M. paranaensis & $\mathrm{P} 1$ \\
\hline Mma 9 & Santa Mariana - PR, Brazil & M. mayaguensis race $2^{\mathrm{a}}$ & M2 \\
\hline Mma 10 & Guanacaste, Costa Rica & M. mayaguensis race 2 & M2 \\
\hline
\end{tabular}

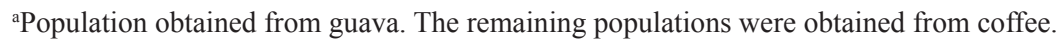

and 'Catuaí Vermelho IAC 144' that was used as susceptible standard.

\section{Nematode resistance evaluation}

Evaluations were carried out 8 months after inoculation. The root systems were carefully washed free of soil, blotted onto paper to damp dry, and weighed (FRW). The whole root system of each plant was soaked in a solution of Phloxine B $(0.015 \mathrm{~g} / \mathrm{L}$ of tap water) for 20 minutes to stain egg masses. Galls and number of egg masses produced by the nematode per root system were counted. Gall Index (GI) and Egg Mass Index (EMI) were calculated according to a scale proposed by Hartman \& Sasser (1985), where $0=$ no galls or egg masses, $1=1-2$ galls or egg masses, $2=3-10$, $3=11-30 ; 4=31-100$, and $5=$ over 100 galls or egg masses. Host-plant type symptoms were observed.

Considering the large size of roots, eggs were extracted by trituration in a blender for 4 minutes in a $1 \% \mathrm{NaOCl}$, according to Hussey \& Barker's (1973) methodology modified by Bonetti \& Ferraz (1981). The number of eggs per root system (final nematode population $=\mathrm{P}_{\mathrm{f}}$ ) was counted in triplicate in a Peter's counting slide. This mean value was used to determine the number of eggs per gram of root (eggs/g root) and the reproductive factor (RF), which represents the relation between final and initial nematode population densities for each treatment $\left(\mathrm{RF}=\mathrm{P}_{\mathrm{f}}\right.$ $\mathrm{P}_{\mathrm{i}}$ ), according to Oostenbrink (1966). The genotypes for which FR $<1$ were considered as highly resistant (HR), and those for which $F R \geq 1$ were considered susceptible $(\mathrm{S})$ or moderately resistant (Sasser et al., 1984). The genotypes were scored as moderately resistant (MR) or resistant (R), according to the terminology proposed by Roberts (2002) and statistical analyses to quantify his concept.

\section{Statistical analyses}

Analysis of variance was performed for the experiment after a $\log (\mathrm{x}+1)$ transformation of the data for the eggs/g root and RF values, and Scott-Knott test $(\mathrm{P} \leq 0.05)$ was used to evaluate differences among genotypes within the same population and differences between populations for the same coffee genotype. Pearson correlation coefficients between fresh root weight (FRW) and FR were calculated for each genotype. Data were analyzed using the SAS statistical package (SAS Institute Inc., 1988).

\section{RESULTS}

\section{Correlations between observed variables}

There were no differences among populations and genotypes for the vegetative parameter plant height during the experiments, and plants showed no obvious aerial symptoms. This is probably the result of the constant fertilization of the coffee plants during the 8 months of the bioassay. Statistical analysis revealed significant effects of coffee genotypes and Meloidogyne spp. populations and the interactions between FRW, eggs/g root and RF $(\mathrm{P} \leq 0.05)$. Only for the genotypes Catuaí Vermelho IAC 144, Sarchimor IAC 4361, Obatã IAC 1669-20 and Paraíso (H 419-5-4-5-2) was FRW significantly correlated to RF, but with low Pearson correlation coefficients $(\mathrm{r}=0.25-0.45)$, showing a small influence of root weight on final nematode population.

The GI (gall index) and EMI (egg masses index) (Table 2) were subjective parameters because some populations formed typical galls and others did not. In some populations the egg masses did not extend beyond the root tissue and in others the egg-masses emerged outside of the roots and were stained with Phloxine B. Considering that, these two parameters (GI and EMI) were used to describe symptoms but not to evaluate nematode infection. Statistical analysis showed that GI and EMI were correlated with coffee infection (RF) for M. exigua $(\mathrm{r}=0.59-0.69$; 0.360.76 , respectively), M. mayaguensis $(\mathrm{r}=0.34-0.51 ; 0.68$ $0.73)$ and Meloidogyne sp. $(\mathrm{r}=0.42 ; 0.58)$, but sometimes with low Pearson correlation coefficient. For M. incognita and $M$. paranaensis GI and EMI were not significantly 
Reaction of coffee genotypes to different populations of Meloidogyne spp.: detection...

Table 2 - Mean values of gall index and egg mass index produced by 10 Meloidogyne spp. populations on seven coffee genotypes

\begin{tabular}{|c|c|c|c|c|c|c|c|c|c|c|c|}
\hline \multirow[t]{2}{*}{ Coffee genotypes } & \multicolumn{11}{|c|}{ Meloidogyne populations } \\
\hline & & Mexi 1 & Mexi 2 & Mexi 3 & Mexi 4 & Minc 5 & Minc 6 & Msp 7 & Mpar 8 & Mma 9 & Mma 10 \\
\hline \multirow[t]{2}{*}{ Catuaí Vermel ho IAC 144} & GI & 5.0 & 5.0 & 4.9 & 3.1 & 2.8 & 3.3 & 0.9 & 3.6 & 1.4 & 3.0 \\
\hline & EMI & 5.0 & 5.0 & 4.4 & 3.1 & 5.0 & 5.0 & 1.1 & 5.0 & 1.4 & 4.3 \\
\hline \multirow[t]{2}{*}{ IAPAR 59} & GI & 0.0 & 0.0 & 5.0 & 0.1 & 3.6 & 3.5 & 0.3 & 3.3 & 3.0 & 2.8 \\
\hline & EMI & 0.0 & 0.0 & 5.0 & 0.0 & 4.9 & 5.0 & 0.5 & 5.0 & 3.6 & 2.3 \\
\hline \multirow[t]{2}{*}{ Obatã IAC 1669-20 } & GI & 2.1 & 2.9 & 5.0 & 0.6 & 3.6 & 4.3 & 1.6 & 3.6 & 0.0 & 3.6 \\
\hline & EMI & 2.0 & 2.9 & 4.8 & 0.3 & 5.0 & 5.0 & 3.3 & 5.0 & 0.0 & 4.6 \\
\hline \multirow[t]{2}{*}{ Sarchimor IAC 4361} & GI & 5.0 & 5.0 & 4.9 & 3.4 & 2.9 & 3.5 & 0.8 & 4.0 & 0.1 & 1.8 \\
\hline & EMI & 4.4 & 5.0 & 4.5 & 3.3 & 5.0 & 4.3 & 2.9 & 4.9 & 0.3 & 0.9 \\
\hline \multirow[t]{2}{*}{ Paraíso (H419-5-4-5-2) } & GI & 0.0 & 0.0 & 5.0 & 0.0 & 2.5 & 4.0 & 0.0 & 4.1 & 0.0 & 2.8 \\
\hline & EMI & 0.0 & 0.0 & 4.4 & 0.0 & 5.0 & 4.9 & 1.9 & 5.0 & 0.0 & 1.6 \\
\hline \multirow[t]{2}{*}{ Tupi Amarelo IAC 5111} & GI & 2.6 & 2.9 & 4.9 & 3.1 & 2.3 & 3.0 & 0.0 & 3.9 & 0.0 & 2.9 \\
\hline & EMI & 1.6 & 2.1 & 3.6 & 2.1 & 4.9 & 4.9 & 0.3 & 4.6 & 1.6 & 1.1 \\
\hline \multirow[t]{2}{*}{ Tupi Vermelho IA C 1669-33 } & GI & 1.0 & 3.8 & 5.0 & 2.5 & 3.3 & 4.4 & 0.0 & 3.4 & 0.1 & 2.3 \\
\hline & EMI & 0.0 & 2.1 & 1.4 & 1.6 & 5.0 & 4.9 & 0.0 & 4.6 & 0.4 & 1.5 \\
\hline
\end{tabular}

Values are means of eight replicate root systems. Population codes are given in Table 1.

Gall Index (GI) and Egg Mass Index (EMI) were based on a $0-5$ scale, where $0=$ no galls or egg masses and $5=$ over

100 galls or egg masses for each root system.

correlated with RF. These pathosystems did not allow the evaluation of nematode infection using GI and EMI.

\section{Coffee genotypes $\mathbf{x}$ M. exigua}

The root symptoms observed were small to large rounded or elongated galls mostly on new roots, which usually contained external and internal egg masses. The cultivars Obatã IAC 1669-20, Sarchimor IAC 4361 and Tupi Amarelo IAC 1669-33 exhibited susceptibility to the four $M$. exigua populations (Tables 3-4). Considering the RF value of 0.7 , cv. Tupi Vermelho IAC 1669-33 can be classified as resistant to the population Mexi 1 from Lavras, MG, Brazil, and susceptible to the others. However, the RFs are relatively small for this cultivar when compared with the others (Table 4).

The reproduction of the populations Mexi1, Mexi 2 and Mexi 4 was very low on IAPAR 59 and Paraíso (H4195-4-5-2) genotypes $(\mathrm{RF}=0.0-0.4)$ (Table 4). In contrast, for the population Mexi 3, collected in Rio de Janeiro State, Brazil, the RF values on these two cultivars were very high: $\mathrm{RF}=165.7$ for IAPAR 59 and $\mathrm{RF}=396.2$ for Paraíso (H 4195-4-5-2). On the IAPAR 59, Obatã IAC 1669-20, Sarchimor IAC 4361 and Paraíso (H419-5-4-5-2) genotypes this population reproduced much more than on Catuaí Vermelho IAC144 (the susceptible control), Tupi Amarelo IAC 5111 and Tupi Vermelho IAC 1669-33 (Tables 3-4).

\section{Coffee genotypes x $M$. incognita}

Coffee plants inoculated with this species showed swellings on the root, some galls and necrosis in the tap roots. Egg masses were produced on the root surface. In general, the coffee genotypes responded differently to the attack of the tested populations. For the population Minc5 race 1, the RFs produced in the Obatã IAC 1669-20 and Tupi Amarelo IAC 5111 genotypes were significantly higher than the remaining genotypes. Moreover, population Minc 6 race 3 also reproduced on all the cultivars, but no significant differences were detected in the RF values (Table 4). Based on the nematode reproduction, all cultivars were considered susceptible to both races of $M$. incognita. Considering the RF values, $M$. incognita race 1 seems to be more aggressive to coffee cultivars than race 3 (Table 4 ).

\section{Coffee genotypes x Meloidogyne sp.}

The inoculated plants had slight symptoms of root destruction and some egg masses were observed in some cultivars. On Catuaí Vermelho IAC 144, Obatã IAC 166920, Sarchimor IAC 4361 and Paraíso (H419-5-4-5-2) genotypes this population reproduced more than on the other genotypes (Table 4), with RF values ranging from 1.1 to 3.9. Although isolated from coffee, the population Msp 7 can be considered as a weak parasite of this host.

\section{Coffee genotypes $\mathrm{x}$ M. paranaensis}

The symptoms observed in the inoculated plants were swellings on the roots, without producing typical root knot nematode galls. Several developed egg masses were observed outside and inside the roots. This population was able to reproduce on all cultivars (Table 4) with RF values ranging from 8.8 to 31.5 . The cultivars IAPAR 59 and Paraíso (H419-5-4-5-2) were as susceptible as the control Catuaí Vermelho IAC 144. The lower RF values observed in Obatã IAC 1669-20, Sarchimor IAC 4361, Tupi Amarelo IAC 5111 and Tupi Vermelho IAC 1669-33 genotypes were 
M.F.S. Muniz et al.

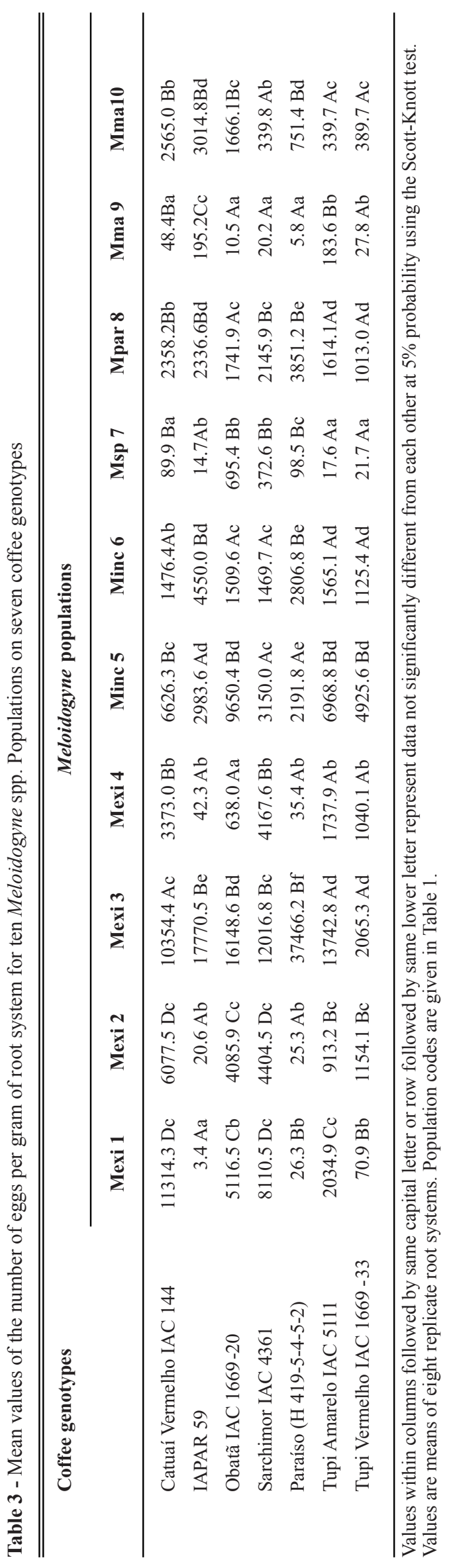


Reaction of coffee genotypes to different populations of Meloidogyne spp.: detection...

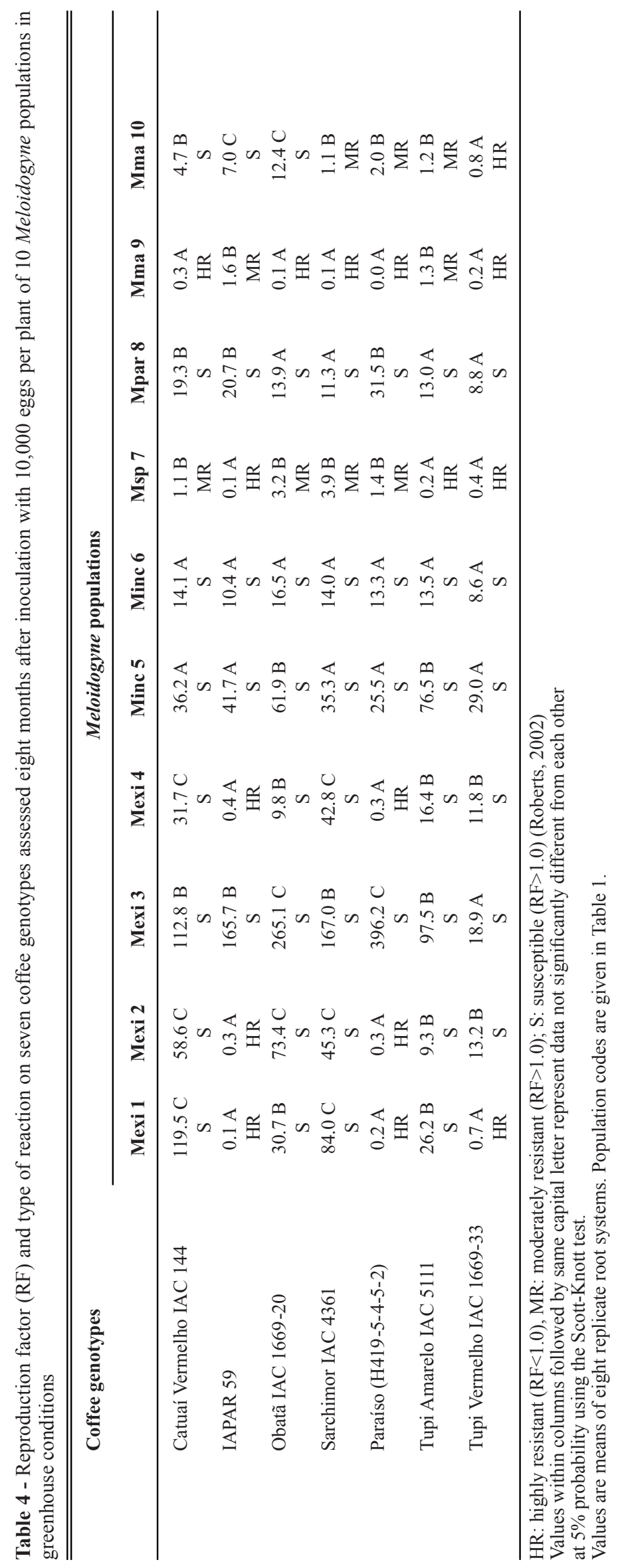


not significantly different from each other. According to the RF values, all the coffee genotypes were susceptible.

\section{Coffee genotypes $\mathbf{x} M$. mayaguensis}

The root symptoms included swellings on the root tips and necrosis. There was no formation of typical galls. Egg masses were observed outside the root tissues. The population Mma 9 from guava reproduced on IAPAR 59 and Tupi Amarelo IAC 5111 cvs with RF values of 1.6 and 1.3, respectively. On the remaining genotypes this population reproduced very weakly $(\mathrm{RF}<1)$ or did not reproduce at all (Tables 3, 4). Therefore, populations of M. mayaguensis from guava can be considered as a weak parasite of coffee.

For the population Mma10 from coffee (Costa Rica) the RF produced on Sarchimor IAC 4361, Paraíso (H 419-5-4-5-2), Tupi Amarelo IAC 5111 and Tupi Vermelho IAC 1669-33 were significantly lower than that observed for Catuaí Vermelho IAC 144, IAPAR 59 and Obatã IAC 1669-20. It should be noted that Tupi Vermelho IAC 166933 showed $\mathrm{RF}<1$. This genotype can be considered as resistant to this population of $M$. mayaguensis from coffee.

\section{DISCUSSION}

The galling and egg mass index were not reliable indicators of nematode multiplication rates because the symptoms of damage caused by different species of Meloidogyne on coffee are variable and very difficult to quantify. Based on these findings, the most pertinent variable for assessing reproduction of Meloidogyne spp. on coffee germplasm and also the host status of the coffee genotype for these nematodes is the number of eggs per gram of roots or the reproduction factor (RF). This result disagrees with the observations made by Hernandez et al. (2004), who considered galling index as a relatively good indicator of nematode multiplication rate for different Meloidogyne species on coffee. Most information on virulence in Meloidogyne spp. is known with regard to the Mi resistant gene in tomato. Selection experiments under laboratory conditions have shown that the proportion of virulent nematodes gradually increases after each successive generation on resistant tomato plants (Netscher, 1977). The same was observed for M. exigua on resistant IAPAR 59 plants (data not shown).

The results of this study were partially consistent with earlier findings by Bertrand et al. (2000) and Salgado et al. (2005). These authors detected the resistance of the cultivar IAPAR-59 to different populations of $M$. exigua. Their resistance was also observed in genotype Paraíso (H419-5-4-5-2) for the three populations of $M$. exigua. However, our results showed the first naturally resistance-breaking field populations of $M$. exigua on the cultivar IAPAR 59 derived from Hybrid carrying the gene Mex-1. In addition, this virulent population was observed even when they were not previously exposed to resistant cultivars. This resistance-breaking was also observed in the Paraíso (H 419-5-4-5-2) genotype. Since $M$. exigua is a meiotic parthenogenetic species (Triantaphyllou, 1985), mechanisms of genetic recombination or other mechanisms must be responsible for the increasing virulence. According to Cook \& Evans (1987), meiotic parthenogenesis maintains the opportunity for sexual reproduction and this permits recombination between homologous chromosomes. These authors suggested that parthenogenesis does not reduce mutation rates and this may generate atypical populations.

This ability to multiply on such cultivars and their uniformly higher rate of reproduction compared with other M. exigua populations used in this study have to be viewed as very important and potentially dangerous characteristics of this population. Other reports of differential behavior of populations of $M$. exigua in Brazil have been suggested by Barbosa et al. (2007); however, the RF value for 'IAPAR 59' and 'Paraíso (H 419-5-4-5-2)' were very small (0.75 and 1.18 , respectively) and it was difficult to characterize the virulence.

The nematode resistance originated from $C$. canephora and introgressed by crossing with Timor Hybrid has been considered as monogenic with an incomplete dominant expression (Noir et al., 2003), and also shown to induce postinfection reaction (Salgado et al., 2005). According to Anthony et al. (2005) resistance conferred by the Mex-1 gene is strongly associated with a hypersensitive reaction (HR). Recently, Alzipar et al. (2007) concluded that Mex-1 could have incomplete dominant expression because most of the F2 populations showed a gall index higher than the mean value of the resistant parent.

In the present work, all coffee cultivars were susceptible to two $M$. incognita populations, but race 1 (EST I1) from São Paulo was more aggressive than race 3 (EST I2) from Paraná State. Several studies have been done on the reaction of $C$. arabica or C. canephora genotypes to $M$. incognita under greenhouse or field conditions in Brazil and other countries (Carneiro, 1995; Anzueto et al., 2001; Hernandez et al., 2004; Tomazini et al., 2005). In these studies, some progenies of $C$. canephora or Ethiopian $C$. arabica accessions were proved to be effective against those nematodes. However, in these studies, the Meloidogyne species were sometimes incorrectly identified (Carneiro et al., 2004).

Meloidogyne sp. collected from coffee in Garça, São Paulo State, presented low aggressiveness to coffee genotypes in greenhouse and field conditions (Gonçalves $\mathrm{W}$, pers. comm.). This population displaying the esterase phenotype $\mathrm{S} 1(=\mathrm{S} 2)$, presented a perineal pattern resembling M. incognita (Oliveira et al., 2006). Other morphological characters using scanning electron microscopy and SCAR markers should be used to characterize this species.

Meloidogyne mayaguensis is considered the most dangerous species in coffee fields in Cuba (Rodríguez et al., 1995; 2001). The two populations of M. mayaguensis (from guava, Brazil and from coffee, Costa Rica) revealed differences in aggressiveness suggesting a physiological 
Reaction of coffee genotypes to different populations of Meloidogyne spp.: detection...

specialization of this species on coffee. Moreover, the low values of RF indicate that coffee is a poor host for $M$. mayaguensis.

In Brazil, M. mayaguensis was reported for the first time in the semi-arid zone of the northeastern region in the States of Pernambuco and Bahia causing severe damage in guava plantations (Carneiro et al., 2001). However, despite its pathogenicity and distribution, there is no report of this species as being a potential coffee parasite in Brazil. Considering the diversity of Meloidogyne species able to parasitize coffee in Brazil and Central America (Carneiro et al., 2004; Hernandez et al., 2004; Muniz et al., 2008) and in terms of virulence, experiments must be conducted with more than one population of each Meloidogyne species when evaluating resistance of new coffee genotypes. Such information will be of considerable interest for the development of integrated management programs and, especially, for the development of durable resistant cultivars adapted to the different situations in coffee-growing areas.

\section{ACKNOWLEDGEMENTS}

We would like to express our gratitude to Dr. Ricardo Moreira de Souza for providing the M. exigua population from Bom Jesus de Itabapoana, RJ, Brazil, and Dr. Benoit Bertrand and Dr. Luc Villain for critical review of the manuscript. We are also grateful to Fundação de Amparo à Pesquisa do Estado de Alagoas - FAPEAL, Brazil, for the scholarship (Process no. 20040930330-0) given to the first author.

\section{REFERENCES}

Almeida EJ, Soares PLM, Silva AR, Santos JM (2008) Novos registros sobre Meloidogyne mayaguensis no Brasil e estudo morfológico comparativo com $M$. incognita. Nematologia Brasileira 32:236-241.

Alzipar E, Etienne H, Bertrand B (2007) Intermediate resistance to Meloidogyne exigua root-knot nematode in Coffea arabica. Crop Protection 26:903-910.

Anthony F, Topart P, Martinez A, Silva M, Nicole M (2005) Hypersensitive-like reaction conferred by the Mex-1 resistance gene against Meloidogyne exigua in coffee. Plant Pathology 54:476-82.

Anzueto F, Bertrand B, Sarah JL, Eskes AB, Decazy B (2001) Resistance to Meloidogyne incognita in Ethiopian Coffea arabica accessions. Euphytica 118:1-8.

Barbosa DHSG, Vieira HD, Souza RM, Dias PD, Viana AP (2007) Desenvolvimento vegetativo e reação de genótipos de Coffea spp. a uma população de Meloidogyne exigua virulenta a cultivares resistentes. Nematologia Brasileira 31:1-6.
Barker KR (1985) Nematode extraction and bioassays. In: Barker KR, Carter CC, Sasser JN (Eds.) An advanced treatise on Meloidogyne, Vol. 2 Methodology. Raleigh NC. North Carolina State University Graphics. pp.19-35.

Bertrand B, Anthony F, Lasherme P (2001) Breeding for resistance to Meloidogyne exigua in Coffea arabica by introgression of resistance genes of Coffea canephora. Plant Pathology 50:637643

Bertrand B, Etienne H, Santacreo R, Anzueto F, Anthony F (2000) El mejoramiento genético en América Central. Proceedings, III International Seminar on Biotechnology in the coffee agroindustry, Londrina PR. pp. 231-243.

Boneti JIS, Ferraz S (1981) Modificação do método de Hussey \& Barker para extração de ovos de Meloidogyne exigua de raízes de cafeeiros. Fitopatologia Brasileira 6:553.

Campos VP, Villain L (2005) Nematode parasites of coffee and cocoa. In: Luc M, Sikora RA, Bridge J (Eds.) Plant parasitic nematodes in subtropical and tropical agriculture. Wallingford UK. CAB International. pp. 529-579.

Carneiro RG (1995) Reação de progênies de Café 'Icatu' a Meloidogyne incognita raça 2, em condições de campo. Nematologia Brasileira 19:53-59.

Carneiro RMDG (2003) Uma visão mundial sobre a ocorrência e patogenicidade de Meloidogyne mayaguensis em goiabeira e outras culturas. Nematologia Brasileira 27:229-230.

Carneiro RMDG, Almeida MRA (2001) Técnica de eletroforese usada no estudo de enzimas dos nematóides de galhas para identificação de espécies. Nematologia Brasileira 25:34-44.

Carneiro RMDG, Carneiro RG, Abrantes IMO, Santos MSNA, Almeida MRA (1996) Meloidogyne paranaensis n. sp. (Nemata: Meloidogynidae), a root-knot nematode parasitizing coffee in Brazil. Journal of Nematology 28:177-189.

Carneiro RMDG, Moreira WA, Almeida MRA, Gomes ACMM (2001) Primeiro registro de Meloidogyne mayaguensis em goiabeira no Brasil. Nematologia Brasileira 25:223-228.

Carneiro RMDG, Tigano MS, Randig O, Almeida MRA, Sarah JL (2004) Identification and genetic diversity of Meloidogyne spp. (Tylenchida: Meloidogynidae) on coffee from Brazil, Central America and Hawaii. Nematology 6:287-298.

Carneiro RMDG, Randig O, Almeida MRA, Gonçalves W (2005) Identificação e caracterização de espécies de Meloidogyne em cafeeiro nos Estados de São Paulo e Minas Gerais através dos fenótipos de esterase e SCAR-Multiplex-PCR. Nematologia Brasileira 29:233-241.

Carneiro RG, Mônaco APA, Moritz MP, Nakamura KC, Scherer A (2006) Identificação de Meloidogyne mayaguensis em goiabeiras e em plantas invasoras, em solo argiloso, no Estado do Paraná. Nematologia Brasileira 30:293-298.

Cook R, Evans K (1987) Resistance and tolerance. In: Brown RH, Kerry BR (Eds.) Principles and practice of nematode control in crops. Marrickville NSW. Academic Press. pp. 179-231.

Gonçalves W, Ferraz LCCB, Lima MMA, Silvarolla MB (1996) Reações de cafeeiros às raças 1, 2 e 3 de Meloidogyne incognita. Summa Phytopathologica 22:172-177.

Hartman KM, Sasser JN (1985) Identification of Meloidogyne species on the basis of differential host test and perineal-pattern 
M.F.S. Muniz et al.

morphology. In: Barker KR, Carter CC, Sasser JN (Eds.) An advanced treatise on Meloidogyne, Vol. 2 Methodology. Raleigh NC. North Carolina State University Graphics. pp. 69-77.

Hernandez A, Fargette M, Sarah JL (2004) Pathogenicity of Meloidogyne spp. (Tylenchida: Meloidogynidae) isolates from Central America and Brazil on four genotypes of Coffea arabica. Nematology 6:205-213.

Hussey RS, Barker KR (1973) A comparison of methods of collecting inocula of Meloidogyne spp., including a new technique. Plant Disease Reporter 57:1025-1028.

Muniz MFS, Campos VP, Castagnone-Sereno P, Castro JMC, Almeida, MRA, Carneiro RMDG (2008) Diversity of Meloidogyne exigua (Tylenchida: Meloidogynidae) populations from coffee and rubber tree. Nematology 10:897-910.

Netscher C (1977) Observations and preliminary studies on the occurrence of resistance breaking biotypes of Meloidogyne spp. on tomato. Cahiers ORSTOM, Series Biologie 11:173-178.

Noir S, Anthony F, Bertrand B, Combes MC, Lashermes P (2003) Identification of a major gene (Mex-1) from Coffea canephora conferring resistance to Meloidogyne exigua in Coffea arabica. Plant Pathology 52:97-103.

Oliveira DS, Oliveira RDL, Gonçalves W (2006) Fenótipo S1 de esterase em Meloidogyne incognita no Brasil. Fitopatologia Brasileira 31:207.

Oostenbrink M (1966) Major characteristics of the relation between nematodes and plants. Mededelingen Landbouwhogeschool Wageningen 66:1-44. (Separate serie no. 357).

Randig O, Bongiovanni M, Carneiro RMDG, Castagnone-Sereno P (2002) Genetic diversity of root-knot nematodes from Brazil and development of SCAR markers specific for the coffee-damaging species. Genome 45:862-870.

Roberts PA (2002) Concepts and consequences of resistance. In: Starr JL, Cook R, Bridge J (Eds.) Plant resistance to parasitic nematodes. Wallingford UK. CAB International. pp. 23-41.
Rodríguez MG, Rodríguez I, Sánchez L (1995) Especies del genero Meloidogyne que parasitan el cafeto en Cuba. Distribucion geografica y sintomatologia. Revista de Protección Vegetal 10:123-28.

Rodríguez MG, Sánchez L, Arocha Y, Peteira B, Solorzano E, Rowe J (2001) Identification and characterization of Meloidogyne mayaguensis from Cuba. Nematropica 31:152.

Salgado SML, Resende MLV, Campos VP (2005) Reprodução de Meloidogyne exigua em cultivares de cafeeiros resistentes e suscetíveis. Fitopatologia Brasileira 30:413-415.

SAS Institute Inc. (1988) SAS/STAT User's Guide. Release 6.03 ed. Cary NC. SAS Institute Inc.

Sasser JN, Carter CC, Hartman RM (1984) Standardization of host suitability studies and reporting of resistance to rootknot nematodes. Raleigh NC. North Carolina State University Graphics.

Silvarolla MB, Gonçalves W, Lima MMA (1998) Resistência do cafeeiro a nematóides V - reprodução de Meloidogyne exigua em cafeeiros derivados da hibridização de Coffea arabica com $C$. canephora. Nematologia Brasileira 22:51-59.

Starr JL, Bridge J, Cook R (2002) Resistance to plant-parasitic nematodes: history, current use and future potential. In: Starr JL, Cook R, Bridge J (Eds.) Plant resistance to parasitic nematodes. Wallingford UK. CABI Publishing. pp. 1-22.

Tomazini MD, Silva RA, Oliveira CMG, Gonçalves W, Ferraz LCCB, Inomoto MM (2005) Resistência de genótipos de cafeeiros a Pratylenchus coffeae e Meloidogyne incognita. Nematologia Brasileira 29:193-198.

Triantaphyllou AC (1985) Cytogenetics, cytotaxonomy and phylogeny of root-knot nematodes. In: Sasser JN, Carter CC (Eds.) An advanced treatise on Meloidogyne. Vol. 1. Biology and Control. Raleigh NC. North Carolina State University Graphics. pp. 113-126.

TPP 8093 - Received 1 August 2008 - Accepted 6 December 2009 Section Editor: Rosangela D'Arc Lima 